\title{
Alternative dispute resolution in the South African pension funds industry: An Ombudsman or a Tribunal? \\ Received: 13th June, 2001
}

\begin{abstract}
John Murphy
is the Pension Funds Adjudicator (the equivalent of the UK Pensions Ombudsman) in South Africa. He is also a Senior Commissioner of the Commission for Conciliation, Mediation and Arbitration, as well as an assessor in the Land Claims Court. He serves as a member of the Council for Medical Schemes and is the Editor in Chief of the Butterworths Pension Law Reports. Prior to his appointment as the Pension Funds Adjudicator, he was employed as Associate Professor and Head of the Department of Public Law in the Law Faculty at the University of the Western Cape, Cape Town. He is a qualified attorney of the High Courts of South Africa and Namibia.
\end{abstract}

\begin{abstract}
This paper argues that South Africa, which has a Pension Funds Adjudicator whose role resembles that of the Pensions Ombudsman in the UK, requires a single, one-stop Pension Complaints Tribunal with exclusive jurisdiction in relation to all pension fund matters arising from whatever quarter. The tribunal model meets the requirements of the South African Bill of Rights more effectively to ensure access to dispute resolution by impartial and independent tribunals.
\end{abstract}

Keywords: complaints procedure; binding decisions; Adjudicator; Ombudsman; Tribunal; ADR; South Africa

\section{The existing framework}

During 1996, pursuant to recommendations made by the Mouton Committee of Investigation into a Retirement Provision System for South Africa, the Pension Funds Act in South Africa was amended to create a special process by which complaints against pension funds can be investigated and decided. A new chapter VA was enacted creating the office of the Pension Funds Adjudicator with the object of disposing of complaints in a procedurally fair,

Professor John Murphy Pension Funds Adjudicator, PO Box 23005, Claremont 7735, Capetown, South Africa.

Tel: +27 02164 0209; e-mail: john@pfa.org.za legislation has borrowed liberally from the provisions establishing the office of the Pension Ombudsman in the United Kingdom. In many respects the two offices resemble each other, function similarly and perform the same tasks. In other respects, mainly because of significant differences in our legal systems, political history and culture, the experience of the two offices is quite different. While the British model has served us well, we are beginning to think that an indigenous model adapted to our peculiar circumstances may suit us better. This occasion, thus, provides a useful opportunity to put forward my views on the matter.

The Mouton Committee economical and expeditious manner. The recommended the appointment of an ombudsman because it felt that this would relieve the pressure on the Financial Services Board, the industry regulator, which was receiving thousands of complaints annually; and also to 
provide an independent service to members of pension funds. It qualified its recommendation with a proposal that the rulings of the ombudsman should not be binding unless a formal procedure, similar to court proceedings, was built into the process. Any legally binding decisions, it maintained, would have to deal with factual questions on a strict basis of proof and on a preponderance of probabilities. Speedy and inexpensive resolution of disputes would not be realised if compulsory binding rulings were to be made.

As it turned out, when the legislation was amended in 1996 to make provision for dispute resolution, the legislature did not implement the Mouton Committee's recommendations entirely. Instead it created the office of an Adjudicator with power to make binding decisions.

Nevertheless, Parliament still chose to model the office on the investigative ombudsman concept rather than opting for a more formal administrative tribunal.

The statutorily defined purpose of the office is to investigate and determine complaints of abuse of power, maladministration, disputes of fact or law, and employer dereliction of duty in connection with pension funds. Although I have the same remedial powers of a court of law, the office is not a court, but an investigative administrative agency.

Our method in investigating and determining complaints resembles that employed by Dr Farrand in the UK. Mostly we proceed by written advocacy, relying on documentation and written submissions. We overcome the ongoing failure by parties to furnish us with sufficient evidence by issuing preliminary determinations giving our prima facie view of the merits on the limited evidence available, and invite the parties to show cause why the proposed order should not be made final. We settle a significant number by negotiation and mediation, often between issuing the preliminary and final order.

The relief against our determinations is much wider than in the UK where it is limited to an appeal on points of law. Section 30P of the Act allows parties to seek relief by means of de novo High Court proceedings within six weeks of the determination, failing which it becomes finally binding. This allows us to proceed creatively and in unorthodox fashion without too much concern about whether our procedures meet the standard of review.

The chosen model naturally has had a bearing upon the practical requirements and workings of the office. The nature and variety of disputes referred for investigation and determination (arising from the wide nature of the jurisdiction) has led, however, to questions about the feasibility of continuing with dispute resolution modelled on the investigative ombudsman concept, and some discussion about restructuring the office to a tribunal akin to the Australian Superannuation Complaints Tribunal.

Despite the introduction of a process which is inexpensive and expeditious, there are often demands from lawyers within the industry for us to adjudicate some complaints using more traditional adversarial methods. Many concede that the investigative approach relying on written advocacy has had considerable success in run of the mill complaints relating to benefit entitlements. Complex matters arising out of restructuring schemes, it is argued, are apt to necessitate more conventional forms.

Over the past three years it has become evident that there is a need for both kinds of dispute resolution, depending on the nature of the complaint and the extent of the relief sought. Whether my office will be in a position to meet these needs will depend on the readiness of the industry and 
government to make the necessary changes and commit adequate resources. Still, experience has led me to the conclusion that the investigative ombudsman model, borrowed from the UK, may not always be the most appropriate means of dispute resolution in respect of pension fund complaints.

Before discussing the proposal for a different model of dispute resolution for pension complaints in South Africa, it might help to consider some of the unique aspects of the South African experience.

\section{Democratisation and human rights}

At 31st December 1998 South Africa had 15,825 registered pension funds, with about $11 \mathrm{~m}$ members, and assets of approximately R604bn. Traditionally, most South African pension funds were defined benefit funds controlled by employers. The trend towards democratisation within South African society over the past 15 years has impacted directly on pension funds, resulting in a legislative requirement that boards of management become representative. In terms of section 7 of the Pension Funds Act, members now have the right to elect 50 per cent of the fund's board of management.

In addition, in 1994 the South African legal system was fundamentally altered with the introduction of a horizontal bill of rights applicable in the private sphere. In an environment marked by increased concentration of economic power in private organisations, the new legal order, consistent with international norms, considers it in the public interest to subject pension funds to human rights standards and the requirements of reasonableness and fairness. Implicit in the shift is the recognition that democracy amounts to something more than extending suffrage to the previously disenfranchised. South Africa's reconstruction aims also at preserving the integrity of our social institutions from corruption and arbitrary or discriminatory practices, by ensuring the just distribution of material and social resources in the bureaucratic decision-making process. All mechanisms of administrative control, therefore, require those who exercise power and make decisions to be held accountable to the democratic enterprise defined in the new social contract, namely, the Constitution. Hence, the creation of a free service to pension fund members for adjudicating claims of maladministration has, besides bringing greater access to justice, imported a quasi-legislative mechanism for setting new standards in an environment where employers previously were subject to little supervision and enjoyed exclusive control.

Partly in anticipation of these changes and partly in response to them, employers, relying on the advice of consultants, began a process of redefining their liabilities towards their employees. Consistent also with international practice, the industry therefore has commenced a process of restructuring, with many employers moving from defined benefit arrangements to defined contribution schemes. Unfortunately, this has happened with inadequate supervision, under legislation conceptualised and enacted in 1956 and updated minimally on a piece-meal basis. With the wisdom of hindsight, it is fair to say that the regulatory framework has not been up to the task. More often than not, member transfer values were calculated unfairly leading, some ten years or more after the event, to calls for my office to intervene and do greater equity retrospectively. For a number of reasons, not least a lack of 
sufficient resources, we have experienced difficulty in meeting this enormous challenge.

\section{Equity on withdrawal and transfer}

The Mouton Committee was quite explicit and deliberate in deciding not to confer an equitable jurisdiction upon my office. Various provisions of Chapter VA make it clear that the jurisdiction of the Adjudicator approximates a court of law, and hence our decisions must be made by reference to principles of law, not equity. Our primary task, furthermore, is rights' adjudication not interest arbitration. As with labour law jurisprudence around the world, disputes of interest are more appropriately resolved by exercises of power and collective bargaining, rather than by rights' adjudication.

In most complaints we are rarely called upon to do equity. The norm is for the complaint to be resolved with reference to the provisions of the rules, the governing legislation, or the common law principles of contract, delict or administrative law. However, it would be misleading to create the impression that we have circumvented questions of equity entirely, or that our jurisdiction is insulated from such concerns. While recognising fully the limits of my authority, I have tried to weave equity considerations into our jurisprudence by reliance on a set of 'disparate and indeterminate strands'. Mainly we have relied on the labour, information and administrative justice clauses in the Bill of Rights, as well as the requirement in section 14 of the Act, that members transferring from one fund to another are entitled to reasonable and equitable transfer arrangements and recognition of their reasonable benefit expectations.

The two areas in which the call for equity has been strongest are revealing of the peculiar conditions under which the South African industry operates; namely, withdrawal benefits and (as just intimated) the distribution of surpluses on transfer. South Africa does not have a requirement of compulsory preservation on termination of employment. Nor does it have tax legislation in place discouraging the accumulation of surpluses. Thus, when members leave employment they are entitled to withdrawal benefits, which in most instances can be paid out in cash. Likewise in the absence of suitable tax legislation, many defined benefit funds have accumulated huge surpluses, the ownership of which has become hotly contested.

The vexed question of fair withdrawal benefits has formed the subject matter of several complaints. Many funds grant patently inequitable benefits on withdrawal by not vesting rights to the employer's contributions. In Kransdorff $v$ Sentrachem Pension Fund \& Another (1999) 9 BPLR 55 (PFA) and Wilson $v$ Orion Fixed Benefit Pension Fund \& Others (1999) 9 BPLR 89 (PFA) we outlined a conceptual framework for reviewing withdrawal benefits in defined benefit schemes. The conclusion we reached was that the inherent limitations of adjudication restrict our scope for intervention since, as with demands for fairer wages, the dispute is usually one of interest and not of right. We proceed from the assumption that the socially desirable object of greater equity on withdrawal from pension funds will best be achieved by legislation or collective bargaining, rather than by adjudication. Were we to strike down inequitable early withdrawal rules as unreasonable or unconstitutional, and to substitute more advantageous rules, we would be entering the arena of setting wages.

These reservations notwithstanding, we are able on occasion to adjust incrementally withdrawal benefits to give 
effect to the constitutional proscription of unfair labour practices. Section 39(2) of the Constitution mandates courts and tribunals, when interpreting legislation or developing the common law, to promote the spirit, purport and objects of the Bill of Rights. Therefore, when rules lack clarity, or are vague and uncertain in their purpose, we shall use the interpretative opportunity to enhance greater fairness in accordance with the spirit of the Constitution. In Wilson, for example, the complainant was paid out his own contributions plus 8 per cent accrued interest. Despite a request for sympathetic consideration, the fund and the company refused to top this up with any payment of the company's contribution. The complainant alleged, among other things, that the withholding of the entire employer portion was in violation of his constitutional rights to fair labour practices. In response the fund contended that the rules did not permit payment of the employer portion, but conceded that some relief could be had by applying the greater benefit rule which granted the employer a discretion to direct the fund to increase benefits on terms and conditions determined by the actuary. We felt a higher benefit was justifiable and ordered an adjustment.

We have also been able to effect some equitable adjustment in transfer situations. As I have said, many of the transfers of members arising out of the restructuring of the industry were effected inequitably, mainly because the members moved with only their resignation benefits, defined ungenerously in terms of the rules of most funds as the member's own contributions plus interest. Members had no entitlement to any part of the contributions made by the employer. Consequently many members left behind in the old fund the employer's contributions, as well as the balance of interest earned in excess of the ungenerous rates of return stipulated in the rules.

Later on, the trend changed and members received transfer values expressed in the amount of their actuarial reserve value, representing the present value of their benefits expected to be paid in the future as a result of service prior to the date of their transfer. Seldom were members given any benefit of the investment reserve (being the difference between the market value and actuarial value of the fund assets) held to protect the fund against a fall in the stockmarket. During the same period the economy saw many retrenchments and, as with resignation benefits, retrenchment benefits were not overly generous.

As a result, the liabilities of defined benefit funds towards their members decreased dramatically while they held on to significant assets surplus to their requirements. In an industry possessed of approximately R680bn worth of assets, it is estimated that the current value of the surpluses (after major restructuring) is at the level of R80-100bn.

Moreover, earlier in the process many administrators and consultants were advising employers that the surplus assets in a defined benefit fund belonged exclusively to the employer. Both the Supreme Court of Appeal and my office subsequently have ruled that any surplus in fact belongs to the fund, not the employer, and should be applied for the benefit of all stakeholders in the fund. The Registrar of Pension Funds has also sought to protect member interests by refusing to allow repatriation of surplus assets to the employers except on extremely strict conditions.

In general, it is fair to say, the process was allowed to proceed without sufficient regulation under antiquated legislation not providing the means to supervise and assess the equity and merits of the schemes. The Financial Services 
Board (the regulator) has recognised this and has proposed legislation for the distribution of the remaining surpluses, taking into account the inequities of past arrangements. To many, the proposal is too little come too late. The redistribution exercise focuses on existing surpluses and will provide redress in respect of past inequitable redistributions only to a limited extent. No matter how regrettable the inequities of the situation, there are obviously sound practical considerations influencing the decision not to seek retrospective redress.

Notwithstanding our limitations, my office has been able to play some role in surplus disputes. We have handed down several decisions defining entitlements and providing redress in relation to inequitable schemes by ordering retrospective enhancements. All the same we tend to approach these matters cautiously, pending guidance from higher courts and Parliament. As we proceed, we recognise that in many cases our scope for intervention is constrained, usually because the relief sought is beyond the limits of adjudication. There are three explanations for this.

- The first is structural or institutional: courts and judicial bodies hesitate to overturn economic distributional decisions on the grounds of equity. Judicial supervision is normally restricted to testing the legitimacy and rationality of a distributional decision. Judges shy away from substituting what they regard as fairer decisions for those of persons better placed to manage the fund's affairs. The board is usually given the benefit of a margin of appreciation, and decisions are upset on review only in cases of disproportionate irrationality.

- Secondly, the courts (and especially my office) lack the resources and the means to embark upon the kind of investigation needed to assess the broader impact of restructuring exercises.

- Thirdly, legitimate grievances about transfer schemes or restructuring arrangements are difficult to remedy years after the event because the practical consequences are too disruptive and difficult to manage.

For these reasons there has been a call for legislation to solve the problems.

\section{The proposed surplus and minimum benefits legislation}

The proposed legislation aims to unlock the existing surpluses sitting in the defined benefits funds for the benefit of all stakeholders, including former members who left with unfair benefits. The regulator has conceded that it was not fair to have given transferring or retrenched members no share of the surpluses in the funds to protect them against the fall in the stockmarket; and that it is thus necessary to legislate a solution apportioning existing surpluses among members, former members, and the employer, with appropriate checks and balances to prevent abuse and to ensure that any unequal bargaining power between employers and members is effectively neutralised.

The Bill aims in the first place to create and define a bedrock of rights in respect of stakeholder claims which at present are moot and debatable. A significant innovation is the recognition of the claims of employers and former members to share in surpluses, with their existing interests being upgraded to the status of statutory rights. As a trade-off, current active members and pensioners shall now enjoy statutory entitlements to minimum benefits.

Most importantly, the Bill compels and 
facilitates a special exercise for the equitable apportionment and creation of rights in existing surpluses. Within the next three years, each fund with a surplus has to come up with a scheme for the equitable apportionment of that surplus; providing for benefit improvements for existing and former members and the crediting of reserve accounts for exclusive utilisation by employers and members respectively.

It is estimated that approximately R80bn shall be apportioned and distributed within 3,000 to 4,000 funds, affecting millions of members. About 4,000 collective bargaining exercises will have to be undertaken. It follows that the propensity for disputes will be high. Assuming a 10 per cent dispute factor, the exercise will engender litigation in relation to assets worth $\mathrm{R} 8 \mathrm{bn}$. This is massive litigation by anyone's standard. Inherent inefficiencies within the system of dispute resolution will pose real obstacles to bringing finality to the exercise.

The Bill proposes ad hoc specialist tribunals (staffed mainly but not exclusively by actuaries) to exist alongside the Adjudicator's office, with the authority to determine the interest disputes which are likely to arise in the surplus redistribution process. The tribunals will essentially have an equity and interest-based jurisdiction, and will function in similar fashion to wage arbitration proceedings. The need for the ad hoc specialist tribunals arises from the fact that my office is insufficiently skilled and resourced to handle the disputes arising out of the exercise. Disputes of interest require different skills to those normally applied in rights' adjudication.

In the main, the legislative proposal is a creative attempt to find a method of alternative dispute resolution for dealing with the multiplicity of claims likely to arise out of the surplus appropriation process. Unfortunately, in my view, it misses the mark on a number of scores. In the first place it leaves potentially complex legal determinations to actuaries who lack the qualifications and experience to make them. Secondly, and more importantly, the arrangement does not provide a comprehensive and exclusive solution to the problem. Despite the attempts to insulate and narrow the complaints jurisdiction of the Adjudicator, it will still be possible for stakeholders to refer a range of collateral and substantive disputes arising out of, connected with, and consequent upon the appropriation exercise to a variety of different forums. These include my office, the ordinary courts, the Commission for Conciliation, Mediation and Arbitration, the Labour Courts, the Equality Courts, the Appeal Board for Financial Services and the Bargaining Councils. Thirdly, the legislation makes the regulator a judge in its own cause by bestowing upon the Registrar of Pension Funds the exclusive right to refer disputes to the tribunals, to the exclusion of other parties who would then be compelled to seek relief in other tribunals.

Because of these unsatisfactory aspects I have challenged the effectiveness of the proposal, and a debate is underway about seeking a more workable alternative.

At the same time, a difference of opinion has arisen between my office and the Financial Services Board concerning the lines of accountability for my office. The governing legislation is somewhat unusual in that it grants to the Financial Services Board, the regulator of the industry, the right to determine my salary and to approve my budget. It also limits my right to exercise certain basic administrative powers, requiring me to seek and obtain concurrence from the 
regulator. Recent events, and the debates concerning the surplus legislation, have shown this arrangement to be less than satisfactory. One reason is that from time to time I shall be called upon to pronounce upon the practices of the regulator in my determinations and to criticise it in public forums. Hence, in my view, it is inappropriate for it to assume the role of managing and controlling my office.

\section{A different model for dispute resolution}

Taken together, these circumstances and considerations have prompted me to call for revisiting the current dispute resolution arrangements with a view to doing away with the ombudsman model, and replacing it with a Pension

Complaints Tribunal akin to the Superannuations Complaints Tribunal in Australia; at the same time incorporating an equitable and interest-based jurisdiction in respect of particular kinds of disputes. My primary motivation is to devise a model getting us away from the existing plethora of competing and overlapping jurisdictions.

Given my preference for the Australian model, I was pleased to receive a copy of Mr Justice Lightman's address earlier this year to the UK Association of Pension Lawyers, in which he too takes issue with the ombudsman model. Although, naturally, I am inclined to side with Dr Farrand in his fascinating duel with Judge Lightman, and while I cannot agree with all that the learned judge has to say, I confess that I am in agreement with his view that disputes about pensions in many instances can be better dealt with by a tribunal employing more formal and conventional adversarial means.

Judge Lightman predicates his argument on the change in legal landscape following the adoption by the
UK parliament of the European Convention on Human Rights, including a fundamental right to a hearing, and hence justifying a different approach.

As with the European Convention, the South African Bill of Rights grants everyone the right to have 'any dispute that can be resolved by the application of law decided in a fair public hearing in a court, or where appropriate another independent and impartial tribunal and forum'. But, as with all rights, this right is subject to proportional limitation or restriction. In South Africa, with the right to a fair trial competing for resources with other more fundamental rights such as the rights to life, dignity and shelter, the Bill of Rights should not be interpreted and applied to impose overly restrictive constraints on alternative means of dispute resolution, especially in our developing world context where we need to inaugurate innovative forms of access to justice, albeit at times seemingly imperfect.

Accordingly, I do not accept the submission that a fundamental right to a hearing, in and of itself, justifies doing away with the investigative model in its entirety. Nevertheless, experience has persuaded me that Judge Lightman is correct in saying that the issues involved or the remedies sought in many pensions cases, far from calling for a summary or cheap procedure, often merit the protection afforded to the parties by more conventional proceedings. Matters involving the distribution of R600m of surplus cannot always be satisfactorily resolved by written advocacy, and without affording the parties a full and proper hearing.

I have come, therefore, to the view that it is important, when establishing an alternative mechanism for dispute resolution in this area, to ensure that intrastructure is created allowing investigative or adversarial processes to be 
matched flexibly to particular disputes, depending on their complexity and the relief sought. The body charged with the responsibility for dispute resolution should thus be clothed with powers enabling it to match disputes and processes appropriately.

I have recently made a proposal for legislative amendments along these lines. In general terms, my proposal is that South Africa requires a single, one-stop, Pension Complaints Tribunal with exclusive jurisdiction in relation to all pension fund matters arising from whatever quarter. The idea is to establish an adjudicative tribunal of first instance, supported by an internal separate mediation service, with litigants enjoying a limited right of appeal, on points of law only, to a specialist Pensions Appeal Tribunal. It allows first for a process of conciliation, fact finding, advisory opinions and preliminary determinations, followed by selective adjudication of significant cases, with a limited right of appeal. Perhaps with the exception of the Financial Services Board, the regulator, the proposal enjoys support within the industry, the legal profession, in government and among trade unions. More importantly, perhaps, it is the model preferred by the staff of the office of the Adjudicator.

The proposed model will satisfactorily address many of the problems we have encountered over the past three years and shall take account of the criticisms of the investigative ombudsman model made by Judge Lightman. In particular, by giving tenure to tribunal members and by statutorily institutionalising greater independence, the tribunal model more effectively meets the requirements of the Bill of Rights to ensure access to dispute resolution by impartial and independent tribunals. A strict internal separation of the process of investigation and mediation from those of adjudication will add to the requirement of impartiality.

Additionally, the tribunal model escapes the unorthodox and uncomfortable practices of our current methodology based on those of the UK Ombudsman. The staff of the office investigate complaints as and when they are received, they report to me and prepare draft decisions for my consideration and signature. As in the $\mathrm{UK}$, this approach is inevitable in view of our substantial workload. In Judge Lightman's words such an approach is 'very troubling', because it means that the procedures are calculated to enable me to sign off decisions effectively made by my staff. There has been a challenge to this practice in an appeal pending before the High Court. In terms of the existing legislation, I am not permitted to delegate my powers of investigation and determination. The point has been taken that my practices clearly amount to an unlawful delegation of power. The tribunal model is one means of getting past this awkwardness.

Finally, the tribunal model is more likely to engender a richer jurisprudence in that all determinations will not be at the hands of a single ombudsman. Tribunal members will be able to disagree with one another and incremental development can occur by means of dissenting judgments. By getting away from the idea of the single ombudsman, one furthermore escapes the negative consequences of associating the personality with the office, as well as the tendency (of which I am certainly guilty) to pursue a high profile 'evangelical agenda' regarded by many as beyond the desirable constraints of judicial office. Judge Lightman captured the point eloquently when he said:

Respectfully I would venture the comment: few postures are so unbecoming 
as a judge, whatever his level in the judicial hierarchy, forever in the missionary position. This must give him the appearance of being, if he is not thereby constituted, an interested party in his own decisions. The obviation of this cloud must be a further factor favouring transferring the adjudicatory role to a tribunal.

\section{Conclusion}

These difficulties and dilemmas aside, when all is said and done, alternative dispute resolution in the pension industry in South Africa has been a great success. Much more has to be done, but I have every confidence we shall reach a satisfactory arrangement soon enough. 